\title{
TOWARDS MANAGEMENT EXCELLENCE: THE CASE OF SOUTH AFRICAN PROFESSIONAL BODIES
}

\author{
S. Naidoo ${ }^{1 *}$ \& A. Rajcoomar ${ }^{2}$
}

\section{ARTICLE INFO}

\section{Article details}

Submitted by authors 26 Apr 2020

Accepted for publication 26 Jul 2020

Available online 31 Aug 2020

Contact details

Corresponding author

naidoosu@unisa.ac.za

Author affiliations

1 Department of Operations Management, University of South Africa, South Africa

2 Department of Management Systems, University of South Africa, School of Business Leadership, South Africa
ABSTRACT

Professional bodies represent practitioners who recurrently seek guidance on industry-related problems and challenges. Research has revealed that professional bodies are lacking in effectiveness and need to improve so that their affiliates can obtain maximum value. The purpose of the study was to empirically develop a framework for the management of professional bodies by exploring the views and opinions of 92 participants employed in the management of professional bodies in South Africa. The data was collected from interviews (pilot) and from a questionnaire (primary instrument) that was analysed statistically, predominantly using factor analysis, to determine the significant factors that contributed to the development of a framework for professional bodies. Eleven significant factors emanated from the factor analysis that informed the empirically developed framework. Government, academics, and management of professional bodies are key beneficiaries of this framework, as it makes a unique contribution to the improvement of professional body management.

\section{OPSOMMING}

Professionele liggame verteenwoordig praktisyns wat herhaaldelik leiding en advies vir industrie verwante probleme en uitdagings benodig. Navorsing toon dat professionele liggame ondoeltreffend is en moet verbeter sodat hul geaffilieerdes maksimale voordeel kan benut. Die doel van hierdie studie is om 'n empiriese raamwerk vir die bestuur van professionele liggame te ontwikkel deur die uitsigte en opinies van 92 meningspeiling deelnemers in diens van die bestuur van professionele liggame in SuidAfrika. Die data is versamel deur onderhoude en deur ' $n$ vraagstuk wat statisties ontleed is, hoofsaaklik deur faktoranalise, om die noemenswaardige faktore wat bygedra het tot die ontwikkeling van 'n raamwerk vir professionele liggame te bepaal. Elf noemenswaardige faktore het voortgespruit uit die faktoranalise. Die Regering, akademici, en die bestuur van die professionele liggame is die sleutel begunstigdes van die raamwerk, omdat dit 'n unieke bydra maak tot die verbetering van die bestuur van professionele liggame.

\section{INTRODUCTION}

Professional organisations are defined as cultured societies whose purpose includes promoting an academic field or a group of disciplines [1]. Societies have a range of membership requirements, and may dictate what minimum qualifications their members must have to practise in the relevant field. Their extensive activities include organising events, organising training for members, and publishing magazines and journals. The International Federation of Accountants [2] states that a professional organisation may recommend codes of practice, either generally or relative to a sector or industry. The body may also exist with the intention of forming local societies that offer a service to a specific group of practitioners.

The South African National Qualifications Framework (NQF) defines NQF levels from 1 to 10. Matriculation from school, for example, is classified NQF 4. A person who has completed school will normally continue with tertiary education from NQF level 5 onwards, possibly to NQF level 8 (Honours level). Once the person enters industry, a professional body is the ideal means of their further skills development. A professional 
body administers skills development by continuing professional development (CPD). We note that professional bodies are now considered part of the strategic learning and skilling infrastructure of South Africa. This relates well to the concept of lifelong learning that is motivated by both personal and professional development.

Professional bodies are affiliation organisations that act in the interests of a specific profession by stimulating and supporting professionals [1]. A professional body is characterised as an organisation that harnesses a body of knowledge and protects it, thereby allowing the professional to act as an agent of formal knowledge [3]. CPD can be viewed in this light, being a mechanism whereby formal knowledge can be continually updated to give legitimacy to the professional's claim. As a mechanism to promulgate professional competence, CPD is widely applied by professional bodies. In South Africa, professional bodies may either be concomitant with government or be independent of government. Some professional bodies are involved in professional certification, and in those instances membership is synonymous with certification. Furthermore, professional bodies regulate entry to a specific profession, ensuring strict entry standards.

Figure 1 illustrates that the NQF comprises three levels. The highest is the Ministry of Basic Education and the Ministry of Higher Education and Training. Professional bodies are classified at the bottom level, as they draw support from the different councils, education authorities, and training authorities that occupy the middle level. According to the South African Qualifications Authority (SAQA) [4], the emergence of the NQF was an attempt by the government to manage the relations between education, training, and work. The structure denotes that professional bodies need to stimulate a collaborative relationship with the education and training authorities in order to optimise the accessible benefits. This configuration further promotes the desire to enable a learned workforce encompassing the principles of the lifelong learning edifice.

\section{The South African NQF System}

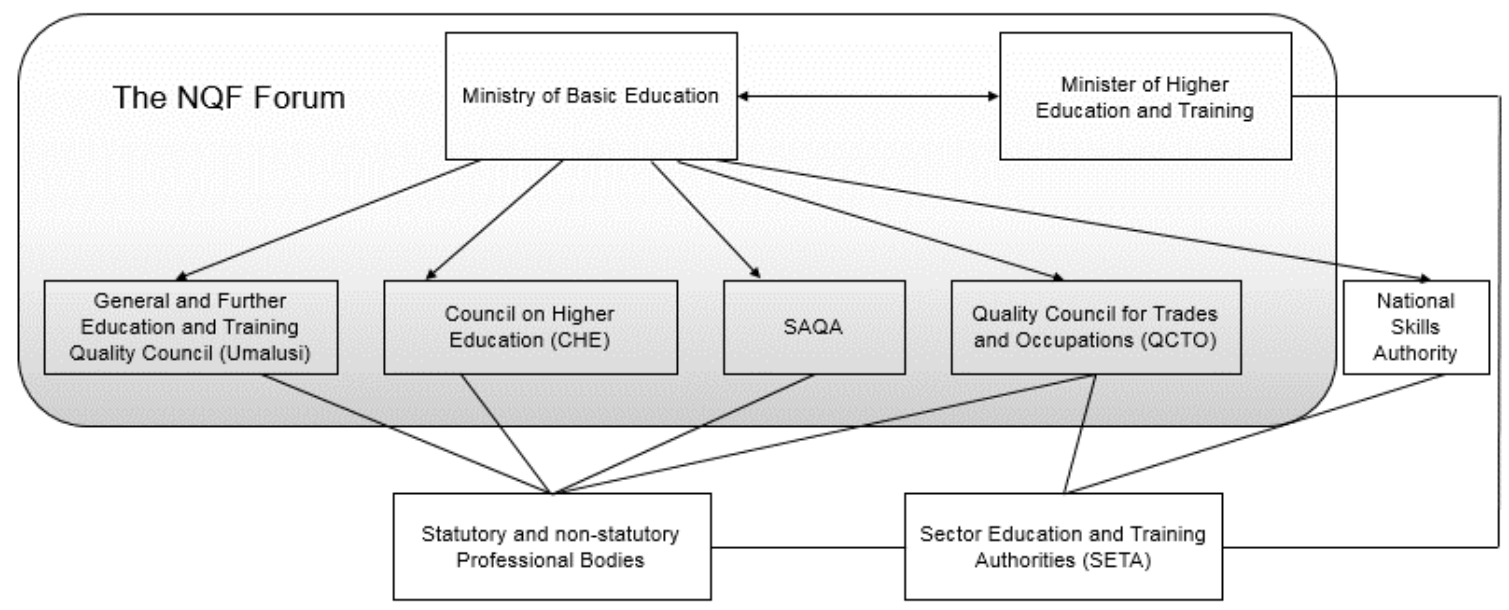

Figure 1: Lessons from the South African National Qualifications Framework (NQF) [4]

\subsection{Background to the study}

SAQA's policy for recognising professional bodies in South Africa [4] states that it promotes public understanding of and trust in professions. The objectives include encouraging social responsibility, promoting pride across all professions, and protecting the public against malpractice. It reiterates the need to build self-esteem and to encourage internationally recognised good practice and the implementation of CPD for members. The promulgation of the policy is binding on SAQA-recognised professional bodies, but only to a lesser extent on those that are not recognised.

According to Fusco, Prescott and Prescott [5], the development of professional attitudes and behaviour is just as critical to providing high-quality service to customers as is the acquisition of knowledge during schooling. The process of professionalisation or professional socialisation (the process of inculcating a profession's attitudes, values, and behaviours in an individual) cannot be learned from a textbook, but must be actively acquired [5]. The development of professionals is undoubtedly the mandate of professional bodies, which also promote proficiency in the field of practice. 
Previous studies on professional bodies have clarified the prevailing positions of selected occupational groups - notably medicine and accounting. Considering the challenges posed by Industry 4.0, professional bodies have an opportunity to showcase the value that can be derived from membership. Unquestionably, all professional organisations have significant contributions to make to the economy. Professional bodies play a major role in refining productivity in their respective industries, thereby benefitting an ailing economy [6]. The calibre of support provided by professional bodies can also prove to be a catalyst for problem-solving in industry, thereby contributing to the stabilisation of the economy [6].

\subsubsection{Declining economic climate}

According to the South African Institute of Professional Accountants' annual report for 2012 [7], the dire economic climate in many countries and the European debt crisis constrained growth in South Africa's economy. They further indicate that their members, who are mostly accountants by profession, provide valuable advice to ailing businesses. The report states that "it is imperative that Professional Accountants are continuously kept up to date through CPD that allow[s] them to gain new knowledge and skills to support their SME clients optimally". It reiterates the need to focus on CPD, acknowledging that the organisation might be lacking in this area [7].

\subsubsection{Declining revenue}

Professional bodies are experiencing declining revenues. The South African Council for Natural Scientific Professions' annual report [8] shows an 11 per cent decrease in revenues for the 2015/2016 financial yearend, compared with the previous year. It states that membership fees made up 63 per cent of its total annual revenue, and that collecting these fees from its members posed a challenge. The Health Professionals Council of South Africa's 2017/2018 annual report [9]) shows a net deficit in revenue generated. This was due to increased operating costs, lower membership fees received than budget for, an increase in building rental fees, increased business process re-engineering project costs, and increased conference costs. The Engineering Council of South Africa's annual report [10] shows that revenue collection decreased substantially. The bulk of their revenue was raised from membership fees. They attribute poor revenue collection partly to economic factors impacting registered members' ability to make payment.

The Independent Regulatory Board for Auditors' annual report [11] reveals a revenue decline for the organisation. The professional body (being a statutory body) receives an annual government grant, which declined from 2015 to 2016 by 13 per cent, to R29 million. This decline resulted in a deficit in income of R3.1 million for 2016.

Professional organisations' declining revenues affect their ability to sustain service levels, especially to their members. Events and other benefits have to be compromised to ensure that expenditure is controlled in accordance with revenues. A gradual decline in membership may result.

\subsubsection{Problem statement}

The South African NQF incorporates levels from 1 to 10 . Matriculation at school is classified as NQF 4. A matriculated person normally continues with tertiary education from NQF 5 to possibly NQF 8 (honours level). Once the person enters an industry, a professional body is the ultimate means of further skills development. As noted in the introduction, CPD is a key part of advancing and monitoring a professional's progress. This relates well to the lifelong concept that is motivated by both personal and professional development.

Therefore professional bodies need to be proficient enough to provide appropriate support to professionals. At present there is no framework to drive the processes of professional bodies. Thus the problem statement is as follows:

There is no framework to manage the operations of professional bodies effectively.

\subsection{Research objective}

To develop a framework that will enhance the management capability of professional bodies.

Since inadequate research has been undertaken on this topic, it was envisaged that the study would significantly develop further theory on professional bodies' achievement of proficiency, contribute to the body of knowledge, and provide a springboard for further study on this and related topics. 


\subsection{NQF recognition benefits for professional bodies}

According to SAQA's policy (2018) [4], SAQA-affiliated professional bodies derive identified benefits. They enjoy a quality assurance role and a qualification development role in collaboration with the Quality Councils. Professional bodies participate in building the national education and training system. They are obliged to provide effective career advisory services to members. They must inspire internationally dominant practices and promote moral practices by professions. Professional bodies must have a good corporate standing, and enhance understanding of, and trust in, professions. An added responsibility is to promote social responsibility and liability in professions. Above all, professional bodies are mandated to uphold the protection of the public [4]. All aspiring professional bodies will ultimately want to be affiliated to SAQA, as the benefits are significant: they increase the value proposition of the organisation, and ambitious professionals will be enticed to join the organisation. Practitioners stand to gain as well, eventually resulting in capable individuals being prepared for industry's challenges.

\subsection{Relationship marketing in associations with membership}

Figure 2 presents a model that was empirically developed, representing a professional association's relationship-building efforts.

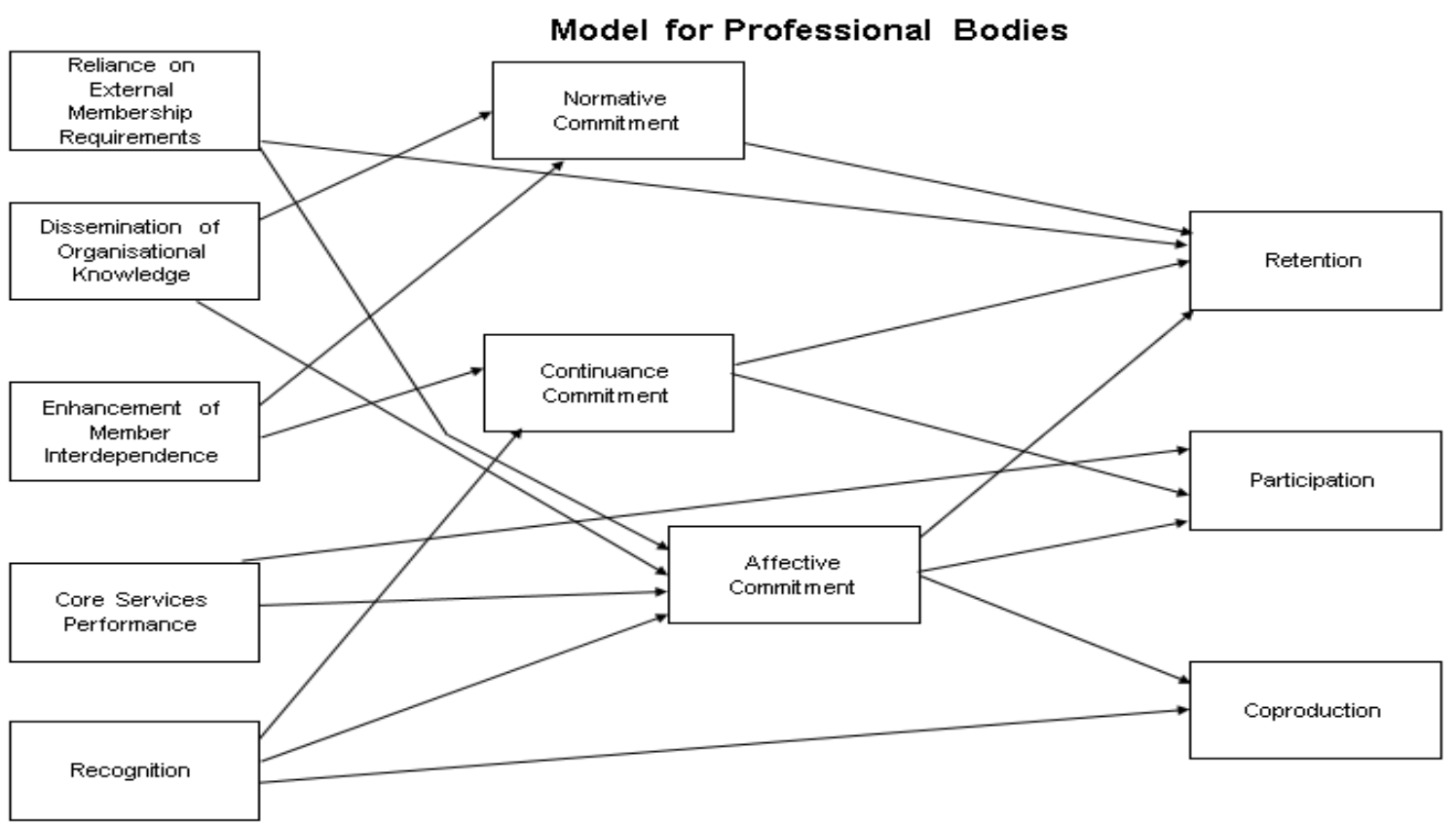

Figure 2: Model for professional associations [12]

\subsection{Membership behaviours: Retention, participation, and co-production}

'Retention' refers to members who opt to remain affiliated to the organisation. The research determined that member retention is a key dimension of an association's performance. Member 'participation' is defined as the extent to which the membership makes use of the association's services, such using a website, reading the trade magazine, attending local meetings, and purchasing additional products and services such as journal subscriptions and educational programming [12]. 'Co-production' is the extent to which members are involved in the production of the association's products, services, and/or marketing.

\subsection{Membership commitment}

'Commitment' is viewed as a motivational phenomenon in the context of the model. Gruen, Summers and Acito [12] describe 'membership commitment' as the degree of the members' psychological attachment to the association. 'Continuance commitment' is described as the extent to which members are psychologically attached to the organisation, based on their perceived moral obligation to it [12]. 'Affective commitment' is focused on the degree to which the members are psychologically bonded to the organisation, based on how favourably they feel about it. 


\subsection{Relating commitment to behavioural outcomes}

The three dimensions of commitment are considered to have a positive relationship with behaviour in organisations. Gruen et al. [12] emphasise that people who have high levels of commitment and are affectively committed to the organisation are willing to give something of themselves to support its wellbeing. The members' loyal payment of prescribed fees represents an initial economic investment in the relationship. This creates a potency that motivates the members to optimise their investments; therefore a link between continuance commitment and participation is predicted. Joining as members and maintaining membership are indicative of a commitment to remain loyal to the organisation.

\subsection{Relationship management activities}

The following analysis of relationship management activities is extracted from Gruen et al.'s study [12]:

- Core services performance. The foundation of any buyer-seller relationship is the supplier's ability to deliver essential value to the customer. In this context, 'core services performance' is defined as the extent of the quantity and quality of the planning and delivery of the association's primary services. Membership organisations that consistently deliver a large range of quality programmes create more opportunities to develop stronger affective attachment in members than those that offer fewer programmes.

- Recognition of contributions. In business-to-business marketing, the benefits that the customer receives from co-production activities may be found in the customisation of the products/services to suit the customer's needs better, in lower prices, and/or in improved delivery. In membership situations, the benefits of co-production co-marketing may be less direct, and much of the motivation is fundamental or, when identification plays a strong role, occurs through continuity with or enhancement of self-esteem.

- Interdependence enhancement. This is defined as the extent to which the organisation offers its members the motivation, opportunity, and ability to exchange value with one another. One of the consistently highest-rated benefits of being a member of the association is the ability to network with other members. Enhancing members' interdependence is expected to affect normative commitment positively. Therefore, these members develop an improved belief that they ought to remain in the organisation so that they do not abandon the other members.

- Dissemination of organisational knowledge. Increasing its knowledge of the customer - or, as popularly stated, "getting close to the customer" - is a crucial ingredient of an organisation's attempts to provide value to its customers. Dissemination of organisational knowledge is a means of improving the socialisation of the members. Members' awareness of the politics, processes, and personnel of the organisation helps them to function more efficiently in the relationship.

- Reliance on external membership requirements. This is defined as the extent to which the association attempts to persuade an intermediary (e.g., an employer) to use its authority to encourage or require the individuals under its authority (e.g., employees) to join and to sustain their membership [12]. The marketing channel concept of 'contact efficiency' speculates that the intercessor generates value for the association through its ability to contact several members, which allows the association to concentrate its marketing effort on a small number of intermediaries.

The model looks at some of the critical areas that an association with members should contemplate in order to remain relevant and credible. The emphasis on membership commitment highlights the human aspect, enticing members into being loyal to the association. The motivation to stay affiliated is highlighted as a driver of membership retention.

\subsection{Sustainability}

In their research, Dickson and Arcodia [13] provide some themes that cast light on the sustainability of professional bodies.

- Corporate social responsibility. This is the first theme deliberated on, and alludes to the notion that professional bodies are obligated to society, and have to plough back added value.

- Training programmes and certifications. The need for professionalism and to uphold the highest standards is essential for a professional body. The nature of a professional occupation is that it encompasses lifelong learning principles - i.e., the required degree of training and education [14], or the application of a unique set of knowledge and skills.

- Benchmarking. Dickson and Arcodia [13] suggest benchmarking as a strategy for improving the operations of a professional body. They indicate that one of the primary functions of a professional 
body is to provide leadership and guidance to members about best practice, both regionally and internationally.

\subsection{Functions and management of the professional body}

Prudent management of a professional body provides many challenges. Theory indicates that there are fundamental functions that the management of an organisation must undertake. Distinguishing between two management function principles, Burns and Stalker's [15] interpretations have been adopted in deliberating on the mechanistic and organic structures.

Table 1: Comparison between mechanistic and organic structures [33]

\begin{tabular}{|l|l|}
\hline \multicolumn{1}{|c|}{ Mechanistic structure } & \multicolumn{1}{c|}{ Organic structure } \\
\hline $\begin{array}{l}\text { Stable environment: This organisational structure } \\
\text { works best when the environment is relatively stable. }\end{array}$ & $\begin{array}{l}\text { Dynamic and uncertain environment: This } \\
\text { organisational structure works best when the } \\
\text { environment is relatively dynamic and uncertain. } \\
\text { High differentiation of tasks: Tasks are changing, and } \\
\text { therefore differentiation may be required, so specialists } \\
\text { are required, with each one being responsible for a few } \\
\text { tasks and able to respond quickly. } \\
\text { stable and easy to control. } \\
\text { High integration: In complex environments, rapid } \\
\text { communication and information sharing is necessary. } \\
\text { The departments and different functional areas need to } \\
\text { be tightly integrated. }\end{array}$ \\
$\begin{array}{l}\text { Low integration of departments and functional areas: } \\
\text { integration between departments and functional areas, } \\
\text { because tasks stay relatively stable and because } \\
\text { functional areas are not heavily dependent on one } \\
\text { another. }\end{array}$ & $\begin{array}{l}\text { Centralised decision-making: When the environment is } \\
\text { stable, there is no need for complex decision-making } \\
\text { that involves people at lower levels. Therefore decision- } \\
\text { making is centralised at the top of the organisation. }\end{array}$ \\
$\begin{array}{l}\text { Standardisation and formalisation: When tasks are } \\
\text { stable, tasks should be standardised so that operations } \\
\text { can run smoothly without breakdowns. }\end{array}$ & $\begin{array}{l}\text { Centralised decision-making: When the environment is } \\
\text { dynamic and uncertain, there is a need for complex } \\
\text { decision-making that involves people at lower levels. } \\
\text { Therefore decision-making power should be distributed } \\
\text { to the lower ranks. }\end{array}$ \\
$\begin{array}{l}\text { Little standardisation and formalisation: When tasks } \\
\text { change rapidly, it is unfeasible to institute standardised } \\
\text { formalised procedures. Instead, tasks should be } \\
\text { manually adjusted so that each sub-task is balanced } \\
\text { with other sub-tasks. }\end{array}$ \\
\hline
\end{tabular}

Professional body management needs to be vigilant by classifying their tasks as either dynamic or stable, and then deciding which management structure to adopt. An organic organisational structure provides for decision-making at lower levels, which may sometimes be viewed as morale boosting to employees if carefully administered. Employees are given the opportunity to work closely in teams rather than being frustrated by a bureaucratic structure. As employees' well-being is provided for through flexibility, adaptability, and job redefinition, innovation can be promoted easily, concomitant with performance.

\section{METHODS AND PROCEDURES}

The methodology encompassed both qualitative and quantitative research approaches. The sample comprised the population of professional bodies in South Africa. All of the professional bodies were targeted; thus no sampling was undertaken. For this study, the qualitative strategy was adopted by conducting interviews, and then the quantitative strategy was used for the analysis of the data. These were effective in that the interviews helped to gain first-hand knowledge from the participants. The interviews also helped to validate the draft questionnaire for professional bodies, which was finalised afterwards. The quantitative approach helped to develop the factors for the framework. 


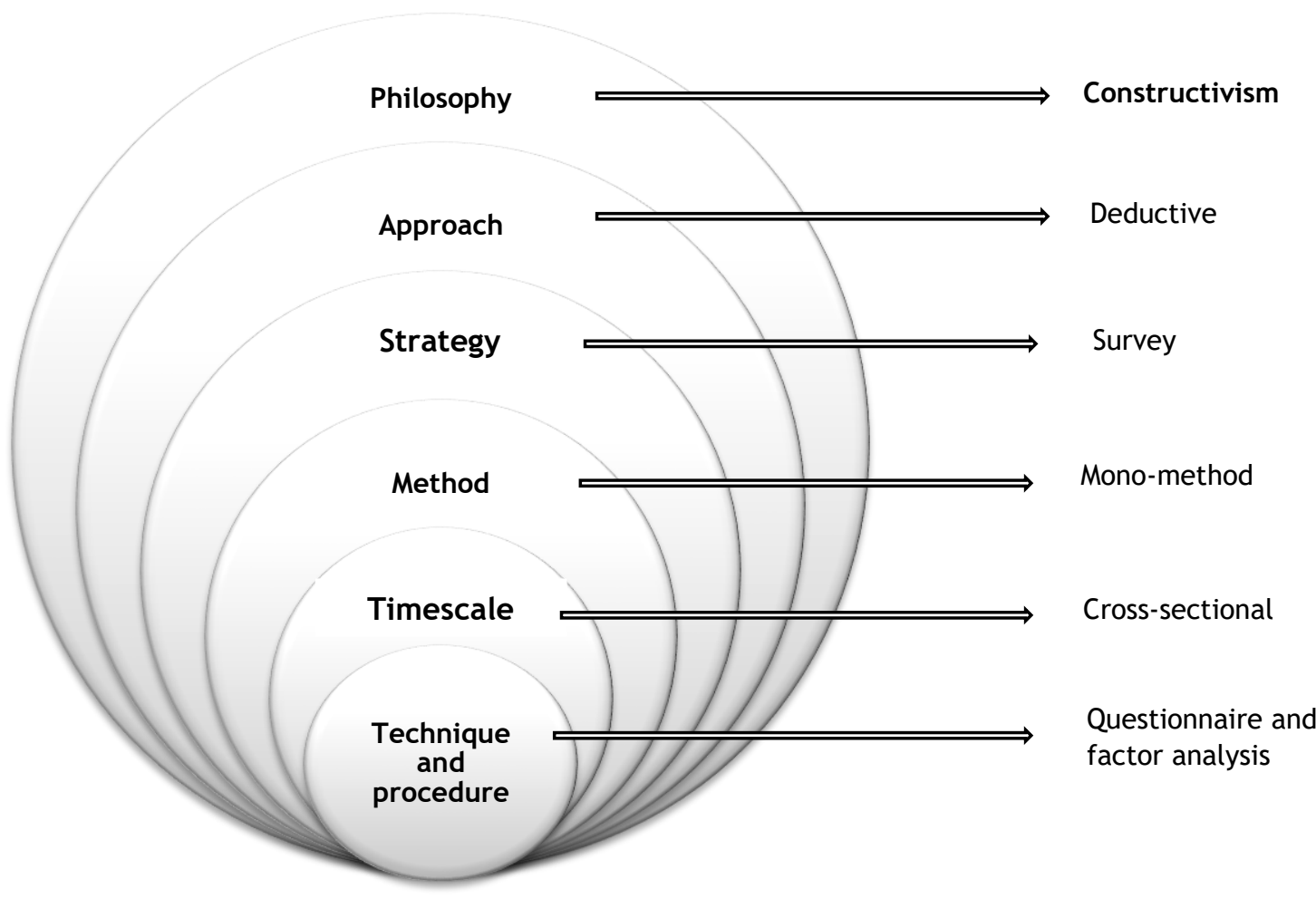

Figure 3: Outline of research philosophy and approach [17]

The research onion (Figure 3), as developed by Saunders, Lewis and Thornhill [17], postulates a flow of academic research. The flow entails the philosophy, approach, strategy, method, timescale, and technique and procedure.

- As part of the research strategy, the constructivist worldview was adopted. The research was dependent on the views and opinions of the selected individuals. Ultimately the researcher had to interpret the meaning others had about the problem being studied.

- As further illustrated in Figure 3, a deductive reasoning approach was undertaken, as it enabled the researcher to test theory based on the literature that had previously been obtained.

- $\quad$ The descriptive path was endorsed, espousing the survey methodology as part of the research strategy.

- $\quad$ The qualitative approach that was followed entailed interviews with three professional bodies; this was viewed as the pilot phase. The sessions were aimed at testing the primary instrument, the main questionnaire, by ensuring that it adequately covered the pertinent areas to be researched. The quantitative approach was then adopted for the analysis of the data using statistical methods. Factor analysis was used to determine the most significant factors that informed the development of the framework for professional bodies.

- $\quad$ Adopting the cross-sectional study approach for the study enabled the gathering of data at a particular point in time.

- As part of the technique and procedure, the questionnaire was structured so that it was precise, informative, and attractive. The front page explained the rationale of the study, and tried to provide a sense of comfort to the respondent by indicating the ethics clearance number from the UNISA School of Business Leadership (SBL) for the research as consent to undertake the research. The first section of the questionnaire was related to the biographical information of the respondent, the profile of the professional body, general yes/no questions, and constructs with related sub-questions. The questionnaire contained statements and questions that adequately addressed the primary and secondary research objectives, as well as the research question. Consideration was given to the fact that respondents would grow weary of a questionnaire with too many questions. Only the most important questions were included because they were believed to contribute valuably to the design of the framework for professional bodies. 


\subsection{Research design}

Punch [16] asserts that the perceived role of a research design is to form a link between the research questions and the data. Design resides between the two, denoting how the research questions will be connected to the data, and the tools and procedures to use in responding to them. The research design essentially must follow from the questions and fit them to the data.

The design of this research was closely linked to the exploratory category. Saunders, Lewis and Thornhill [17] indicate that the techniques of conducting exploratory research are the following:

- $\quad$ The search of the literature - journals and books were used for this study.

- Interviewing subject matter experts - interviews were separately conducted with three professional bodies.

An extensive search for apposite literature was conducted using journals, books, and other published works. The results of the literature review and the interviews enabled the preparation of a comprehensive questionnaire, ensuring that all the significant themes were covered. The interviews with professional body managements allowed for the questionnaires to be enhanced. All ambiguous questions were excluded. The questionnaire was posted online so that respondents could participate in the study in the most objective and dispassionate manner.

\subsection{Response rate}

Table 2: Population and sample size

\begin{tabular}{|l|l|l|l|}
\hline Target population & Responses received & Rejected & Accepted population \\
\hline 119 professional bodies & 92 & 0 & 92 \\
\hline
\end{tabular}

As can be seen from Table 2, the response rate was high, with 92 (77\%) of the targeted 119 professional bodies participating in the research.

\section{RESULTS AND DISCUSSION}

Table 3 presents the participants' response statistics and the reliability statistics for the 11 significant factors.

Table 3: Reliability statistics

\begin{tabular}{|c|c|c|c|c|c|}
\hline $\begin{array}{c}\text { Item } \\
\text { number }\end{array}$ & Concept & Mean & $\begin{array}{l}\text { Standard } \\
\text { deviation }\end{array}$ & $\begin{array}{l}\text { Cronbach's } \\
\text { alpha for } \\
\text { each factor }\end{array}$ & $\begin{array}{l}\text { Cronbach's } \\
\text { alpha if item } \\
\text { deleted }\end{array}$ \\
\hline \multicolumn{2}{|c|}{ Factor 1: Mandate of professional body } & & & 0.643 & \\
\hline 1 & $\begin{array}{l}\text { Keep members well informed and } \\
\text { knowledgeable about the latest elements and } \\
\text { operational procedures of the best } \\
\text { professional projects and strategic plans being } \\
\text { implemented locally and globally. }\end{array}$ & 6.522 & 0.502 & & 0.673 \\
\hline 2 & $\begin{array}{l}\text { Promote adherence to benchmarks for } \\
\text { standards as accepted by the best } \\
\text { practitioners in the world. }\end{array}$ & 5.891 & 0.313 & & 0.667 \\
\hline 3 & $\begin{array}{l}\text { Encourage programmes to implement the } \\
\text { continuous professional development of } \\
\text { existing members. }\end{array}$ & 6.783 & 0.440 & & 0.601 \\
\hline 4 & $\begin{array}{l}\text { Devise, enforce and administer a } \\
\text { comprehensive code of ethical standards and } \\
\text { procedures. }\end{array}$ & 6.957 & 0.253 & & 0.613 \\
\hline 5 & $\begin{array}{l}\text { Make a range of considered benefits available } \\
\text { to all the accredited members. }\end{array}$ & 6.598 & 0.515 & & 0.568 \\
\hline 6 & $\begin{array}{l}\text { Oversee the development of training } \\
\text { programmes and the certification of } \\
\text { professional qualifications. }\end{array}$ & 5.196 & 0.497 & & 0.589 \\
\hline 7 & $\begin{array}{l}\text { Act in the interests of the public in relation to } \\
\text { the services provided by members and the } \\
\text { associated risks. }\end{array}$ & 6.109 & 0.654 & & 0.578 \\
\hline 8 & $\begin{array}{l}\text { Promote the imperatives of the government } \\
\text { and enforce legislation. }\end{array}$ & 3.902 & 0.785 & & 0.620 \\
\hline
\end{tabular}




\begin{tabular}{|c|c|c|c|c|c|}
\hline $\begin{array}{l}\text { Item } \\
\text { number }\end{array}$ & Concept & Mean & $\begin{array}{l}\text { Standard } \\
\text { deviation }\end{array}$ & $\begin{array}{l}\text { Cronbach's } \\
\text { alpha for } \\
\text { each factor }\end{array}$ & $\begin{array}{l}\text { Cronbach's } \\
\text { alpha if item } \\
\text { deleted }\end{array}$ \\
\hline 9 & $\begin{array}{l}\text { Recognise suitable education and training } \\
\text { providers, and be involved in the curricula of } \\
\text { learning programmes offered by education } \\
\text { and training providers. }\end{array}$ & 5.250 & 1.323 & & 0.580 \\
\hline \multicolumn{2}{|c|}{ Factor 2: Role of members } & & & 0.690 & \\
\hline 10 & $\begin{array}{l}\text { Members serve on committees/ councils } \\
\text { formed within the body. }\end{array}$ & 5.620 & 1.090 & & 0.626 \\
\hline 11 & $\begin{array}{l}\text { Members provide advisory services to the } \\
\text { board of directors/ councils/ committees. }\end{array}$ & 5.630 & 0.540 & & 0.612 \\
\hline 12 & $\begin{array}{l}\text { Members are involved in the administration of } \\
\text { the body. }\end{array}$ & 3.670 & 1.000 & & 0.670 \\
\hline 13 & $\begin{array}{l}\text { Members provide articles for publication } \\
\text { purposes. }\end{array}$ & 6.070 & 0.530 & & 0.758 \\
\hline 14 & $\begin{array}{l}\text { Members offer voluntary assistance to the } \\
\text { operations activities of the body. }\end{array}$ & 5.730 & 0.920 & & 0.554 \\
\hline 15 & $\begin{array}{l}\text { Members assist with the planning of } \\
\text { conferences and workshops or other } \\
\text { functions. }\end{array}$ & 6.750 & 0.620 & & 0.629 \\
\hline \multicolumn{2}{|c|}{ Factor 3: Leadership provided to members } & & & 0.828 & \\
\hline 16 & $\begin{array}{l}\text { The leadership style of the organisation } \\
\text { empowers members. }\end{array}$ & 6.010 & 6.011 & & \\
\hline 17 & $\begin{array}{l}\text { Members are supportive of the leadership } \\
\text { style of the organisation. }\end{array}$ & 6.000 & 6.000 & & \\
\hline \multicolumn{2}{|c|}{ Factor 4: Offerings and benefits } & & & 0.678 & \\
\hline 18 & Assists with job placements. & 5.910 & 0.590 & & 0.570 \\
\hline 19 & Develops standards of practice. & 6.100 & 0.330 & & 0.667 \\
\hline 20 & Assists with career development. & 6.290 & 0.760 & & 0.577 \\
\hline 21 & $\begin{array}{l}\text { Promotes training, conferencing, workshops } \\
\text { and seminars in terms of CPD. }\end{array}$ & 6.420 & 0.540 & & 0.707 \\
\hline 22 & $\begin{array}{l}\text { Offers opportunities to network with other } \\
\text { members. }\end{array}$ & 6.020 & 0.150 & & 0.724 \\
\hline 23 & $\begin{array}{l}\text { Encourages contribution to newsletters and } \\
\text { other publications. }\end{array}$ & 6.020 & 0.150 & & 0.724 \\
\hline 24 & $\begin{array}{l}\text { Provides knowledge and support to members } \\
\text { through helplines. }\end{array}$ & 5.890 & 1.260 & & 0.596 \\
\hline 25 & Provides a system of grading members. & 5.920 & 0.540 & & 0.595 \\
\hline 26 & $\begin{array}{l}\text { Ensures members are up to date with the } \\
\text { practices needed by the professional. }\end{array}$ & 5.790 & 0.900 & & 0.588 \\
\hline \multicolumn{2}{|c|}{ Factor 5: Assurance mechanisms } & & & 0.699 & \\
\hline 27 & $\begin{array}{l}\text { The organisation monitors practitioners' } \\
\text { performance and progress. }\end{array}$ & 5.707 & 0.806 & & 0.377 \\
\hline 28 & $\begin{array}{l}\text { The organisation regularly communicates best } \\
\text { practices to practitioners. }\end{array}$ & 5.870 & 0.338 & & 0.812 \\
\hline 29 & The organisation has a quality plan in place. & 5.543 & 0.831 & & 0.354 \\
\hline \multicolumn{2}{|c|}{ Factor 6: Financial analysis } & & & 0.559 & \\
\hline 30 & The organisation is financially sustainable. & 5.970 & 0.350 & & 0.525 \\
\hline 31 & The organisation has many sponsors/ donors. & 5.690 & 0.810 & & 0.528 \\
\hline 32 & $\begin{array}{l}\text { The organisation receives financial support } \\
\text { from industry. }\end{array}$ & 5.550 & 1.290 & & 0.442 \\
\hline 33 & $\begin{array}{l}\text { The organisation receives some financial } \\
\text { support from Sector Education and Training } \\
\text { Authorities (SETAs) and other government } \\
\text { structures. }\end{array}$ & 2.720 & 1.580 & & 0.564 \\
\hline 34 & $\begin{array}{l}\text { The organisation has a prescribed fee } \\
\text { structure in place for each grade of } \\
\text { membership. }\end{array}$ & 6.410 & 0.500 & & 0.540 \\
\hline 35 & $\begin{array}{l}\text { The intention of the professional body is to } \\
\text { make a profit. }\end{array}$ & 4.860 & 1.250 & & 0.462 \\
\hline \multicolumn{2}{|c|}{ Factor 7: CPD support } & & & 0.851 & \\
\hline 36 & $\begin{array}{l}\text { CPD is concerned with maintaining } \\
\text { knowledge, skills and competencies; in other } \\
\text { words, CPD is about keeping up-to-date. }\end{array}$ & 6.260 & 0.470 & & 0.847 \\
\hline
\end{tabular}




\begin{tabular}{|c|c|c|c|c|c|}
\hline $\begin{array}{c}\text { Item } \\
\text { number }\end{array}$ & Concept & Mean & $\begin{array}{l}\text { Standard } \\
\text { deviation }\end{array}$ & $\begin{array}{l}\text { Cronbach's } \\
\text { alpha for } \\
\text { each factor }\end{array}$ & $\begin{array}{l}\text { Cronbach's } \\
\text { alpha if item } \\
\text { deleted }\end{array}$ \\
\hline 37 & $\begin{array}{l}\text { CPD improves and broadens knowledge and } \\
\text { skills; in other words, CPD is intended to } \\
\text { support future professional development. }\end{array}$ & 6.350 & 0.500 & & 0.851 \\
\hline 38 & $\begin{array}{l}\text { CPD is intended to develop the personal } \\
\text { qualities and ethical capacities necessary to } \\
\text { execute professional and technical duties. }\end{array}$ & 6.080 & 0.540 & & 0.834 \\
\hline 39 & $\begin{array}{l}\text { CPD should enable professionals to improve } \\
\text { their performance in their current role. }\end{array}$ & 6.850 & 0.510 & & 0.809 \\
\hline 40 & $\begin{array}{l}\text { CPD should enable professionals to take on } \\
\text { new roles. }\end{array}$ & 6.770 & 0.630 & & 0.808 \\
\hline 41 & $\begin{array}{l}\text { CPD should improve career prospects with } \\
\text { current employers or in current practice. }\end{array}$ & 5.990 & 0.350 & & 0.808 \\
\hline 42 & $\begin{array}{l}\text { CPD should support career progression to new } \\
\text { employers or to different practices. }\end{array}$ & 6.150 & 0.590 & & 0.846 \\
\hline \multicolumn{2}{|c|}{ Factor 8: Partnerships and collaborations } & & & 0.601 & \\
\hline 43 & $\begin{array}{l}\text { The organisation works in partnership with } \\
\text { businesses in industry. }\end{array}$ & 5.598 & 0.839 & & \\
\hline 44 & $\begin{array}{l}\text { The organisation is actively involved in } \\
\text { standards setting with the South African } \\
\text { Bureau of Standards and other stakeholders. }\end{array}$ & 2.163 & 0.893 & & \\
\hline \multicolumn{2}{|c|}{ Factor 9: Research activities } & & & 0.645 & \\
\hline 45 & $\begin{array}{l}\text { The organisation is actively and continuously } \\
\text { involved in research projects. }\end{array}$ & 5.163 & 1.207 & & 0.587 \\
\hline 46 & $\begin{array}{l}\text { Practitioners produce articles and papers that } \\
\text { are published in journals. }\end{array}$ & 5.076 & 1.162 & & 0.623 \\
\hline 47 & $\begin{array}{l}\text { Research is conducted for the benefit of the } \\
\text { sector. }\end{array}$ & 5.924 & 0.559 & & 0.572 \\
\hline 48 & $\begin{array}{l}\text { Research is conducted for the benefit of the } \\
\text { country. }\end{array}$ & 5.228 & 0.648 & & 0.617 \\
\hline 49 & $\begin{array}{l}\text { Research is conducted for the benefit of the } \\
\text { association. }\end{array}$ & 5.304 & 1.340 & & 0.630 \\
\hline 50 & $\begin{array}{l}\text { Research is conducted for the benefit of the } \\
\text { members. }\end{array}$ & 5.949 & 0.428 & & 0.591 \\
\hline \multicolumn{2}{|c|}{ Factor 10: Events and activities } & & & 0.601 & \\
\hline 51 & $\begin{array}{l}\text { Only local speakers are used to present at } \\
\text { events. }\end{array}$ & 2.196 & 0.802 & & \\
\hline 52 & $\begin{array}{l}\text { Only international speakers are used to } \\
\text { present at events. }\end{array}$ & 2.022 & 0.444 & & \\
\hline \multicolumn{2}{|c|}{ Factor 11: Importance of professional body } & & & 0.824 & \\
\hline 53 & $\begin{array}{l}\text { The organisation sets standards that guide the } \\
\text { industry. }\end{array}$ & 6.080 & 0.310 & & 0.875 \\
\hline 54 & $\begin{array}{l}\text { The organisation is involved in the skills } \\
\text { development of practitioners in collaboration } \\
\text { with SAQA. }\end{array}$ & 4.790 & 2.510 & & 0.731 \\
\hline 55 & $\begin{array}{l}\text { The organisation mentors practitioners on } \\
\text { methods to transfer skills effectively to young } \\
\text { talent. }\end{array}$ & 5.410 & 1.420 & & 0.807 \\
\hline 56 & $\begin{array}{l}\text { The organisation lobbies government } \\
\text { organisations such as SETAs and the Quality } \\
\text { Council for Trade and Occupations (QCTO) so } \\
\text { that the profession can benefit. }\end{array}$ & 4.120 & 1.940 & & 0.702 \\
\hline 57 & $\begin{array}{l}\text { The organisation acts in the best interests of } \\
\text { the public. }\end{array}$ & 6.020 & 1.660 & & 0.705 \\
\hline
\end{tabular}

Table 3 shows each factor with the related sub-questions and statistics. The 'Cronbach's alpha for each factor' and the 'Cronbach's alpha if item is deleted' are shown for each sub-question. Where the reliability value was low, the highest 'Cronbach's alpha if item is deleted' value was deleted in order to increase the overall reliability of the construct. The statistical reliability of each construct is therefore above the limit of 0.600 , which justifies the conclusion that each of the 11 factors may be regarded as relevant. 


\subsection{Development of significant factors and discussion}

\section{Table 4: Empirically significant factors and relevance}

\begin{tabular}{|c|c|}
\hline Significant factor & Relevance to the research \\
\hline $\begin{array}{l}\text { 1. Member and } \\
\text { industry support }\end{array}$ & $\begin{array}{l}\text { Through the research, it emerged that support from the professional body is lacking, and } \\
\text { is most needed by members and industry. 'Support' refers to the professional body taking } \\
\text { charge of the career progression of members and collaborating with industry to solve } \\
\text { problems. Professional bodies should coordinate advances in innovation and stimulate the } \\
\text { uptake of new practices and technologies. The support should also result in spin-offs such } \\
\text { as industry financial support to professional bodies. }\end{array}$ \\
\hline $\begin{array}{ll}\text { 2. } & \text { Professional } \\
& \text { development }\end{array}$ & $\begin{array}{l}\text { Professional development arose from the sub-factors of education, workshops, and } \\
\text { training. Respondents agreed that the professional development of members is a core } \\
\text { output of professional bodies, and requires impetus. Professional bodies are urged to } \\
\text { organise more events and workshops that involve members as contributors to professional } \\
\text { development. Industry tours are also considered part of the development roadmap for } \\
\text { members. }\end{array}$ \\
\hline $\begin{array}{l}\text { 3. CPD support to } \\
\text { members }\end{array}$ & $\begin{array}{l}\text { The research showed that some professional bodies do not offer CPD. Using a point } \\
\text { allocation system is common practice in most professional bodies; it works well as a } \\
\text { measurement tool, and obligates members to participate in developmental activities. } \\
\text { SAQA requires all affiliated professional bodies to administer CPD to members. }\end{array}$ \\
\hline $\begin{array}{ll}\text { 4. } & \text { Assurance } \\
& \text { mechanisms }\end{array}$ & $\begin{array}{l}\text { The research showed that robust quality assurance mechanisms in professional bodies are } \\
\text { lacking. Mechanisms such as regular auditing of member development, logs and } \\
\text { checklists, monitoring systems, and communication tools are not used by professional } \\
\text { bodies. }\end{array}$ \\
\hline $\begin{array}{ll}\text { 5. } & \text { SAQA } \\
& \text { collaboration }\end{array}$ & $\begin{array}{l}\text { Since several professional bodies are not recognised by SAQA, they do not collaborate } \\
\text { with SAQA, and so certain benefits offered by SAQA are not accessible to them. Benefits } \\
\text { such as funding, training, and development for members are absent. According to SAQA } \\
\text { [4], professional bodies must engage with the QCTO and other educational bodies to } \\
\text { design learnerships for their members. }\end{array}$ \\
\hline $\begin{array}{ll}\text { 6. } & \text { Member } \\
\text { involvement }\end{array}$ & $\begin{array}{l}\text { The research showed that member involvement in the organising of events, the } \\
\text { development of training programmes, etc. is required so that members' self-esteem can } \\
\text { be raised. Members also want to be involved in research projects that may be related to } \\
\text { problem-solving in the industry. }\end{array}$ \\
\hline $\begin{array}{l}\text { 7. Standards setting } \\
\text { for industry }\end{array}$ & $\begin{array}{l}\text { Professional bodies long to be considered custodians of standards setting for industry. } \\
\text { Through increased research and collaboration, professional bodies can control standards } \\
\text { in specific industries to help promote uniformity. This will lead to the adoption of best } \\
\text { practices that can improve the quality of service and products. }\end{array}$ \\
\hline Standardisation & $\begin{array}{l}\text { Research conducted by PARN [18] showed that, when members work towards specific } \\
\text { benchmarks, employers and the public are assured of good service. Standardisation in a } \\
\text { professional body is considered beneficial, but it could also be detrimental, especially } \\
\text { when a sensible solution to a problem differs from the prescribed standards. This could } \\
\text { lead to some members being frustrated with the standard processes that may not meet } \\
\text { their needs at times. Standardisation can at times stifle innovation. It is therefore } \\
\text { recommended that professional bodies carefully consider the implications of standardised } \\
\text { processes and continually re-evaluate them. }\end{array}$ \\
\hline 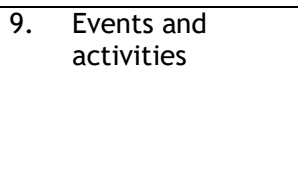 & $\begin{array}{l}\text { There is a strong desire for members to be involved in events and activities. This adds to } \\
\text { members' development, and provides them with the opportunity to get away from their } \\
\text { work places and to engage with their professional bodies. It also gives members the } \\
\text { opportunity to network with one another, discuss industry-related problems, and seek } \\
\text { solutions collectively. }\end{array}$ \\
\hline $\begin{array}{ll}\text { 10. } & \text { Regular } \\
\text { communication }\end{array}$ & $\begin{array}{l}\text { Regular communication has many advantages, and serves to keep members up-to-date. It } \\
\text { promotes a good impression of the professional body. }\end{array}$ \\
\hline 11. Benchmarking & $\begin{array}{l}\text { As part of SAQA's mandate, international collaboration with other professional bodies is } \\
\text { encouraged and supported. Benchmarking against international standards can be achieved } \\
\text { quite easily if professional bodies seek international affiliation. }\end{array}$ \\
\hline
\end{tabular}

There were eleven factors that were statistically significant. Table 4 outlines the final developed significant factors, which emerged from the statistical analysis as those that most informed the developed framework.

\subsection{The developed framework}

The framework for the management of professional bodies is presented in Figure 4. It provides empirical evidence of the pertinent areas that require particular consideration by professional bodies. It also incorporates the theoretical underpinnings of the output that is needed, which is the excellence that a professional body will achieve. Through the prolonged use of this framework, it is envisaged that professional bodies will improve their operations in each of the areas, and ultimately achieve management excellence. 


\section{Professional body excellence framework}

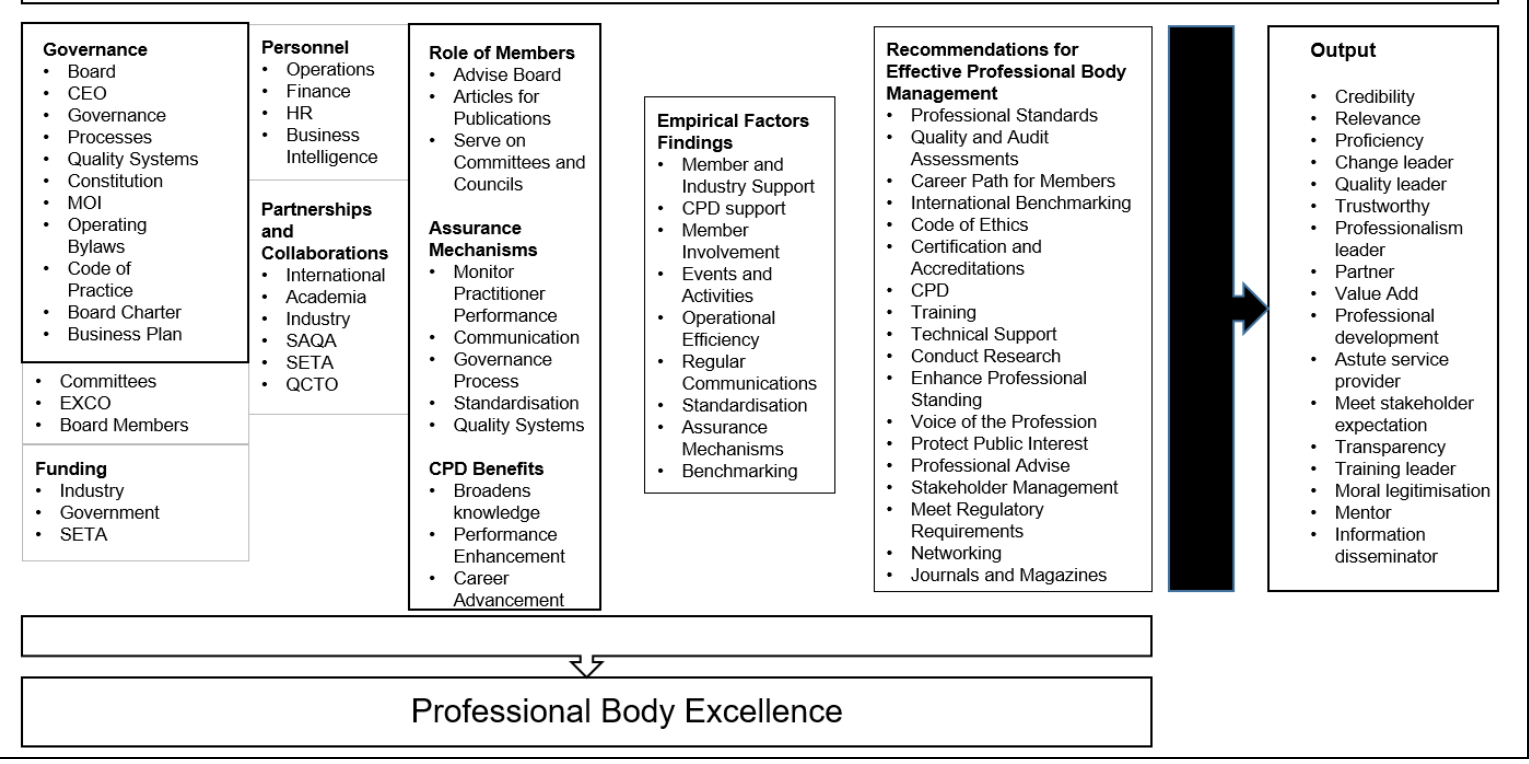

Figure 4: Framework for professional body excellence (source: authors)

\subsection{Ethical considerations}

The respondents participated in the survey willingly, and their identities were not disclosed, in accordance with their request.

\section{CONCLUSION}

The conclusion is discussed with reference to the achievement of the objective.

\subsection{Achievement of the objective}

To develop a framework that will enhance the management capability of professional bodies.

The collated management activities of a professional body are ratified and informed by the empirical findings and related literature. The prudent practice of professional bodies is dependent on effective management.

The factors that were significant for the management of professional bodies are: member and industry support, CPD support to members, member involvement, events and activities, operational efficiency, regular communication, standardisation, assurance mechanisms, and benchmarking. Each of these factors is empirically viewed as the focal areas for a professional body to practise with proficiency.

One of the myths of good service delivery by professional bodies is that ceremonial activities must be adhered to, for example organising an annual conference for members. The lack of flexibility associated with ceremonial activities results in compromised performance, which is mostly detrimental to the credibility of such bodies. The other concern is that ceremonial rules are transmitted from multiple parts of the environment, which results in rules conflicting at times. These inconsistencies raise concern about effectiveness when tight coordination and control are problematic. The last area of concern is that professional bodies decouple structure from activities. The more highly institutionalised the environment, the more that time and effort are directed to manage the organisation's public image and status, and the less that time is devoted to boundary-spanning activities. The bureaucratisation of professional bodies is considered a hindrance to the execution of certain tasks, and threatens the efficiency of their operations. The operations of professional bodies should be aimed at satisfying their members as part of their basic functions. Members today have a demanding mindset, with which the professional body needs to keep up with. 'Member involvement' emerged from the data as a significant factor. The respondents indicated that members displayed heightened discontent in the absence of professional body support and limited opportunities. 
In SAQA's policy for the recognition of professional bodies, the importance of the professional body applying sound principles in recognising a community of experts is highlighted. Emphasis is also placed on providing learnerships for members with the QCTO and other educational bodies. SAQA also stresses the protection of community interests in relation to the services rendered. The development of designations is an added responsibility of professional bodies. A code of conduct to manage members is mandatory for all professional bodies. Career-related information and advice must be a standard service of all professional bodies.

Professional bodies need to take a leading role in improving productivity within their respective industries. Productivity improvements can be intensified if professional bodies increase efficiency in their operations. The impact of their role in increasing the skills level of members and the general capability of the workforce and management by promoting best practices and sharing the latest innovations should not be underestimated. The contribution of professional bodies is also indirect in promoting trust and reducing uncertainty. Furthermore, professional bodies help to co-ordinate advances in innovation and stimulate the uptake of new practices and technologies.

SAQA views professional bodies as part of the nucleus of the NQF, and they must pursue international affiliation at all costs for the benefit of their members. SAQA reiterates that professional bodies' mandate is to provide members with a set of professional standards, either through local development or through custodianship of international standards.

\subsection{Benefits of the study}

Professional bodies can make use of the framework developed through this research by implementing it in their organisations. This research has identified areas that require changes in the practice of professional bodies in order to promote efficiency. Their engagement in research will encourage members by giving them the opportunity to contribute to publications that can be made available industry-wide. Members should be given the opportunity to be more enthusiastically involved in the operations of their professional bodies. The research identified this area as apposite in motivating members. Professional bodies should collaborate actively with academia, the SETAs, and the QCTO so that the development of their members can be structured in a meaningful way.

\subsection{Limitations}

Limitations reduce the extent of the study, and may affect the end results and, by extension, the paucity of empirically grounded theory on professional bodies in South Africa and internationally. However, this study was valuable in addressing the lack of a framework for professional bodies.

\subsection{Recommendation}

The determination and implementation of international best practices can contribute to new ways of doing things that are accepted by the international community. Professional bodies are encouraged to develop relationships with academia and skills development authorities for the purpose of determining the key training and development needs of their members. This can result in the right programmes to empower members.

\section{REFERENCES}

[1] Higher Education Better Regulation Group (HEBRG). 2011. Professional, statutory and regulatory bodies: An exploration of their engagement with higher education. Available: https://www.universitiesuk.ac.uk/policy-andanalysis/reports/Documents/2011/hebrg-professional-bodies.pdf [Accessed: 10 June 2019].

[2] International Federation of Accountants IFAC). 2008. Approaches to continuing professional development (CPD) measurement. Available: https://www.ifac.org/publications-resources/approaches-continuing-professionaldevelopment-cpd-measurement-ies-7-support- [Accessed: 11 February 2017].

[3] Paisey, C. \& Paisey, N.J. 2018. Protecting the public interest? Continuing professional development policies and role-profession conflict in accountancy. Critical Perspectives on Accounting. Available: https://doi.org/10.1016/j.cpa.2018.04.002 [Accessed 5 May 2019].

[4] South African Qualifications Authority (SAQA). 2017. Assessment of the impact of the South African National Qualifications Framework. Available: http://www.saqa.org.za/ [Accessed: 5 June 2019].

[5] Fusco, N.M., Prescott, G.M. \& Prescott, W.A., Jr. 2015. Currents in Pharmacy Teaching and Learning, 7(1), 117120.

[6] Green, B. 2015. Understanding the value of professionals and professional bodies. Available: https://www.ciob.org/sites/default/files/CIOB\%20research\%20-\%20Professions\%20Report.pdf [Accessed: 1
[1 February 2017]. 
[7] SAIPA. 2012. Annual integrated report. Available: https://www.saipa.co.za/wp-content/uploads/2017/01/5369SAIPA-Annual-Report-A4-Por_Rev11.pdf [Accessed: 1 February 2017].

[8] South African Council for Natural Scientific Professions (SACNASP). 2016. Annual report 2015/2016. Available: https: / /www.sacnasp.org.za/upload-8s/files/2016-Annual-Report.pdf [Accessed: 1 February 2017].

[9] Health Professions Council of South Africa (HPCSA). 2018. Annual report. Available: file:///C:/Users/DRRAJ/Desktop/Paper\%20for\%20IBC/hpcsa_annual_report_2017_2018.pdf [Accessed: 2 February 2017].

[10] Engineering Council of South Africa (ECSA). 2016. Annual report 2015/2016. Available: https://www.ecsa.co.za/news/Annual\%20Reports/Annual_Report_2015-2016.pdf [Accessed: February 2017].

[11] Independent Regulatory Board for Auditors (IRBA). 2016. Annual report. Available: http://www.irbalearning.co.za/upload/ANNUAL\%20REPORT\%202016\%20final.pdf [Accessed: 15 February 2017].

[12] Gruen, T.W., Summers, J.O. \& Acito, F. 2000. Relationship marketing activities, commitment and membership behaviours in professional associations. Journal of Marketing, 64(3), 34-49.

[13] Dickson, C. \& Arcodia, C. 2010. Promoting sustainable event practice: The role of professional associations. International Journal of Hospitality Management, 29(2), 236-244.

[14] Greenwood, R., Suddaby, R. \& Hinings, C.R. 2002. Theorizing change: The role of professional associations in the transformation of institutionalized fields. Academy of Management Journal, 45(1), 58-80.

[15] Burns, T. \& Stalker, G.M. 1961. The management of innovation. The Economic Journal, 79(314), $403-405$.

[16] Punch, K.F. 2000. Developing effective research proposals. London: SAGE.

[17] Saunders, M., Lewis, P. \& Thornhill, A. 2012. Research methods for business students, 6th ed. Harlow: Prentice Hall.

[18] PARN. 2012. A new professional body for quality improvement. Journal of Quality Professionals, $2(2), 1$ - 8. 